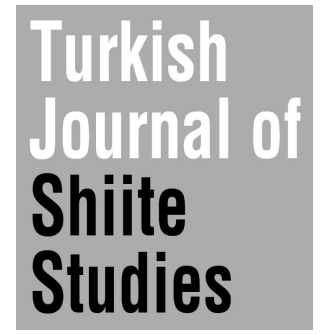

ISSN: 2687-1882

Cilt / Volume: 3

Say1 / Issue: 2

Aralık / December 2021

\title{
Şî̂ Düşüncenin Hâkimiyetindeki İran'da Tefsîr Eğitimi: Tahran Üniversitesi İlahiyat Fakültesi Tefsîr Bölümü Örneği
}

Tafsir Education in Iran Dominated by Shiite Thought: An Example of the Tafsir Department of the Faculty of Theology of the University of Tehran

\section{Mehmet Beşir ERGIN}

Arş. Gör., Marmara Üniversitesi İlahiyat Fakültesi,

Res.Assist., Marmara University, Faculty of Theology, İstanbul/TURKEY

besirah1958@hotmail.com https://orcid.org/0000-0003-0103-3595

Harun ASLAN

Arş. Gör., Kırşehir Ahi Evran Üniversitesi İslami İlimler Fakültesi,

Res.Assist., Kırşehir Ahi Evran University, Faculty of Islamic Sciences, Kırşehir /TURKEY

harunilahiyat04@gmail.com https://orcid.org/0000-0003-1444-7607

\section{Makale Bilgisi/Article Information}

Makale Türü/Article Type: Araştırma Makalesi / Research Article

* Bu çalışma, 28-30 Mayıs 2021 tarihlerinde Artuklu Üniversitesi tarafından Mardin'de düzenlenen “ïslam Dünyasında Üniversiteler ve İslami İlimler Uluslararası Sempozyumu”"nda sunulan “İran'da İlahiyat Fakülteleri: Tahran Üniversitesi İlahiyat Fakültesi Üzerine Bir Analiz” isimli tebliğin bir bölümünün geliştirilerek makaleye dönüştürülmüş halidir. (This study is the developed of a part of the paper titled "Faculties of Theology in Iran: An Analysis on the Faculty of Theology of Tehran University" presented at the International Symposium on Universities in the Islamic World and Islamic Sciences organized by Artuklu University on May 28-30, 2021 in Mardin.)

Geliş Tarihi / Date Received: 21.11.2021

Kabul Tarihi / Date Accepted: 16.12.2021

Yayın Tarihi /Date Published: 31.12.2021

DOI: https://doi.org/10.48203/siader.1026724

Atıf/Citetion: Ergin, Mehmet Beşir-Aslan, Harun. “Şiî Düşüncenin Hâkimiyetindeki İran'da Tefsîr Eğitimi: Tahran Üniversitesi İlahiyat Fakültesi Tefsîr Bölümü Örneği”. Turkish Journal of Shiite Studies 3/2 (Aralık 2021): 167-182. doi: 10.48203/siader.1026724

İntihal: Bu makale, Turnitin yazılımınca taranmıştır. İntihal tespit edilmemiștir. Plagiarism: This article has been scanned by Turnitin. No plagiarism detected.

Web: https://dergipark.org.tr/tr/pub/siader mailto: turkishshiitestudies@gmail.com 


\begin{abstract}
Tafsir education, which is carried out with the aim of understanding and interpreting the Qur'an in today's Islamic countries, is carried out informally within different institutions, as well as officially in higher educational institutions. The Theological faculties are the places where this education is given in universities. The faculties of theology include many disciplines such as figh, hadith, kalam, Sufism and so on. The Faculty of Theology of the University of Tehran in Iran, which is the center of Shiite thought, is also one of these institutions. In that faculty, the department of exegesis conducts its educational activities as a separate department along with hadith at the undergraduate level. In the department, the courses of the two fields are taken as a common measure in the first years and are separated according to the tendency of the student in the following years. Compulsory and basic courses are mostly about courses related to the general Islamic disciplines, while specialized and elective courses are aimed at the field. In this context, exegesis courses are intensively processed in the category of specialized courses. In this study, first of all, the general framework of the Faculty of Theology of the University of Tehran, one of the well-established and modern educational institutions of Iran, which is managed under the umbrella of the Shia sect, is focused on; then, the course curriculum in the department of Qur'anic Sciences, which is the basis of the study, is limited to the undergraduate level and is considered in a descriptive way.
\end{abstract}

Keywords: Exegesis (Tafsîr), Shia, Qur'anic Sciences, Tehran University Faculty of Theology, Curriculum

\title{
Öz
}

Günümüz İslâm ülkelerinde Kur'ân'ı anlama ve yorumlama gayretiyle gerçekleştirilen tefsîr eğitimi gayrî resmî olarak farklı kurumlar bünyesinde gerçekleştiği gibi resmî olarak yüksek öğretim kurumlarının uhdesinde de icra edilmektedir. Üniversitelerde bu eğitimin verildiği yerler ise İlahiyat Fakülteleridir. İlahiyat Fakülteleri fikıh, hadîs, kelâm, tasavvuf ve benzeri birçok disiplini bünyesinde barındırmaktadır. Şiî düşüncenin merkezi olan İran'daki Tahran Üniversitesi İlahiyat Fakültesi de bu kurumlardan biridir. Söz konusu fakültede tefsîr bölümü lisans düzeyinde hadîsle birlikte müstakil olarak eğitim faaliyetlerini yürütmektedir. Bölümde iki alana ait dersler ilk senelerde ortak olarak tedrîs edilirken sonraki yıllarda öğrencinin eğilimine göre birbirinden ayrılmaktadır. Umûmî (Üniversite tarafindan Konulan Zorunlu Dersler) ve Pâye (Temel Dersler) dersleri daha çok İslâmî disiplinlerin geneli ile ilgili dersler hakkında iken, uzmanlık ve seçmeli dersler ise alana yönelik olmaktadır. Bu bağlamda tefsîr dersleri uzmanlık/ihtisâs dersleri kategorisinde yoğun bir şekilde işlenmektedir. Bu çalışmada öncelikle Şia mezhebi çatısı altında yönetilen İran'ın köklü ve modern eğitim kurumlardan biri olan Tahran Üniversitesi İlahiyat Fakültesi'nin genel çerçevesi üzerinde durulmakta; ardından çalışmanın ana nîrengini oluşturan Kur'ân İlimleri bölümündeki ders müfredatı lisans düzeyi ile sınırlandırılarak tasvîrî bir şekilde ele alınmaktadır.

Anahtar Kelimeler: Tefsîr, Şia, Kur'ân İlimleri, Tahran Üniversitesi İlahiyat Fakültesi, Müfredat

\section{Giriş}

Hz. Muhammed'in vefatından sonra başlayan Kur'ân'ı anlama ve yorumlama faaliyeti çerçevesinde tefsîr eğitimi günümüze kadar varlığını sürdürmüş ve hala da bu eğitim süreci devam etmektedir. Bu bağlamda Müslüman ülkelerde çeşitli kurum ve 
merkezlerde tefsîrle ilgili çalışmalar yapılmaktadır. Bu ülkelerden biri de Şî̂ (İsnâaşeriyye) düşüncenin günümüzdeki merkezi olan İran'dır. Tefsîr tedrîsâtı İran'da çeşitli kurumlar vasıtasıyla gerçekleştirilmektedir. Köklü bir ilmî geleneğe sahip olan İran'da tefsîr eğitimi veren kurumlara bakıldığında Şiî düşüncenin bütün yönleriyle ele alındığı havza-i ilmiyyeler, araştırma merkezleri ve üniversiteler bünyesindeki İlahiyat Fakülteleri önümüze çıkmaktadır. Havza-i ilmiyyeler ağılıklı olarak İsnâaşeriyye paradigmasının daha baskın olduğu Kum şehrinde faaliyet göstermesinin yanı sıra İsfâhân ve Meşhed gibi diğer bölgelerde de eğitim ve öğretimi icra etmektedir. Söz konusu bu medreselerde fikıh ve hikmet (Hikmet-i Müteâliye) dersleri yoğunlukta olmakla birlikte tefsîr derslerine de ayrıca yer verilmektedir. ${ }^{1}$ Bunun yanında Kur'ân ilimleri ile de ilgili birçok araştırma merkezi bulunmaktadır. 1363/1984 yılında Defter-i Teblîgât-i İslâmî Havza-i İlmiyye’ye bağlı olarak faaliyetlerine başlayan Pejûheşgâh-i 'Ulûm ve Ferheng-i İslâmî bu kurumlardan birisidir. ${ }^{2}$ Bünyesinde kelâm, fikıh, Şia tarihi, Mehdeviyyet (Mehdîlikle ilgili araştırmalar) araştırmaları ve benzeri birçok çalışma grubu muhtevi bu kurum, Kur'ân ve tefsîr alanında ise 'Ulûm-i Kur'ânî, Tefsîr-i Kur'ânî, Ferhengnâmehâ-yi Kur'ânî ve Dâiretu'l-Maârifhâ-yi Kur'ânî araştırma gruplarını bulundurmaktadır. Söz konusu gruplar çalışmalarında birçok tefsîr, kitap ve makale yayımlamıştır. ${ }^{3}$

Kum'da tefsîr faaliyetlerini yürüten bir diğer araştırma merkezi ise Pejûheşgâh-i 'Ulûm-i Vahyânî-yi Maâric'tir. Bünyesinde Kur'ân ve 'itret (Ehl-i Beyt), 'Ulûm-i Aklî olmak üzere iki alt araştırma merkezi barındıran kurum, ${ }^{4}$ özellikle Kur'ân ve tefsîr sahasında birçok çalışma yürütmektedir. Eserlerin içerik olarak daha çok mehdilik, velâyet ve imâmların görüşü gibi Şiî düşüncenin esâslarını oluşturan meseleler hakkında olduğunu söylemek mümkündür. Kur'ân ez-Manzar-i İmâm Rizâ (İmâm Rıza'ya Göre Kur'ân), Tecelliy-i Velâyet der Âye Tathîr (Tathîr Âyetinde Velâyetin Zuhûru), Velâyet der Kur'ân (Kur'ân'da Velâyet) gibi çalışmalar bu hususu teyid etmektedir. ${ }^{5}$

İran'da tefsîr eğitim ve öğretiminde bulunan ve aynı zamanda Kur'ân ilimleri ile ilgili araştırma yapan önemli kurumlardan birisi ise Yükseköğretim Kurumları bünyesindeki üniversitelerdir. İran'da yüksek din öğretimi üniversitelerdeki İlahiyat Fakültelerinde yürütülmektedir. Dolayısıyla tefsîr eğitimi de bu fakültelerde verilmektedir. İran'da üniversiteler bünyesinde tefsîr eğitimi ilk olarak Tahran Üniversitesi İlahiyat Fakültesi bünyesinde başlamıştır. Ayrıca daha sonraki yıllarda Kur'ân-1 Kerîm adıyla müstakil üniversiteler de kurulmuştur. Bu üniversitelerden biri de 1361/1982 yılında kurulan ve Merkezi Tahran'da bulunan Maârif İlimleri ve Kur'ân1 Kerîm Üniversitesi'dir. ${ }^{6}$ Lisans 'Ulûm-i Kur'ân ve Hadîs, Yüksek Lisans 'Ulûm-i Kur'ânî, 'Ulûm-i Kur'ân ve Hadîs doktora düzeyinde Tefsîr-i Tatbîkî-yi Kur'ân alanında eğitim vermektedir.7

Vikifikh Dânişnâme-i Havza, “Havza-i İlmiyye” (Erişim 18.11.2021).

Pejûheşgâh-i Ulûm ve Ferheng-i İslâmî, "Muerrefî-yi Pejûheşgâh ve Pejûheşgedehâ” (Erişim 18.11.2021)

Pejûheşgâh-i Ulûm ve Ferheng-i İslâmî, "Guruhhâ-yi İlmî” (Erişim 18.11.2021).

Pejûheşgâh-i Ulûm-i Vahyani-yi Maâric (İsra), “Pejûheşgede-i Kur'ân ve Itret” (Erişim 18.11.2021).

Pejûheşgâh-i Ulûm-i Vahyani-yi Maâric/İsra), "Âsâr” (Erişim 18.11.2021).

Danişgâh-i Ulûm ve Maârif-i Kur’ân-1 Kerîm, “Muerrefî-yi Danigâh” (Erişim 18.11.2021).

Danişgâh-i Ulûm ve Maârif-i Kur'ân-1 Kerîm, “Listi Riştehâ-yi Tahsîlî” (Erişim 18.11.2021). 
İran İlahiyat Fakültelerinde tefsîr dersleri lisans, yüksek lisans ve doktora düzeyinde hadîs dersleri ile birlikte ele alınmaktadır. Başka bir ifade ile tefsîr alanında ihtisâs yapmak isteyen bir öğrenci tefsîr derslerinin yanı sıra hadîs derslerini de görmektedir. Fakat tefsîr dersleri hadîse nispeten daha ayrıntılı işlenmekte ve müfredat olarak da daha çok yer tutmaktadır. Yüksek lisans ve doktora düzeyinde ise öğrenci bu iki ilimden birini tercih ederek tez çalışmasını yapmaktadır. ${ }^{8}$ Ayrıca tefsîr ile ilgili akademik çalışmalar yürüten birçok dergi aynı zamanda hadîsle ilgili araştırmaları da içermektedir. Söz gelimi bu dergiler Mutâlaât-i Kur'ân ve Hadîs, Mutâlaât-i Tatbîki-yi Kur'ân ve Hadîs ve Mutâlaât-i Terceme-i Kur'ân vb. isimlerle yayın faaliyetlerini yürütmektedir. ${ }^{9}$

Biz de bu çalışmamızda Tahran Üniversitesi İlahiyat Fakültesindeki Lisans düzeyinde tefsîr eğitim ve öğretimini müfredat bakımından tasvîrî olarak ele almaya çalışacağız. Bu bağlamda ilk olarak İlahiyat Fakültesinin genel tarihçesinden söz edip, Kur'ân ilimleri ve hadîs bölümündeki tefsîrle ilgili derslerin isimleri ve içeriği hakkındaki bilgileri ele almaya çalışacağız.

\section{Tahran Üniversitesi İlahiyat Fakültesi}

Tahran Üniversitesi İran'ın modern anlamındaki ilk üniversitesidir. İçerisinde birçok farklı bölümü barındıran bu üniversite 1313/1934 yılında Aklî ve Naklî İlimler Fakültesi adıyla günümüzdeki İlahiyat ve İslâmî İlimler Fakültesini bünyesine katmıştır. İlk olarak Arap Edebiyatı, Aklî İlimler ve Naklî îlimler olmak üzere üç bölümle tedrîsata başlayan fakülte, beş yıl boyunca eğitim öğretime devam ettikten sonra 1318/1939 yılında kapatılmıştır. 1321/1942 yılında tekrar eğitime açılarak Aklî ve Naklî İlimler olmak üzere iki bölümle faaliyetlerini yürütmüştür. Sonraki yıllarda ise Arap Dili ve Edebiyatı, İslâm Kültürü bölümlerini bünyesine katmıştır. 1344/1965 yılında ise Aklî ve Naklî İlimler Fakültesi İlahiyat ve İslami İlimler ismini almıştır. ${ }^{10}$ Günümüzde ise Şâfiî Fıkhı, Felsefe ve İslâm Kelâmı, Tarih ve İslâm Milletleri Medeniyeti, Fıkıh ve İslâm Hukuku Esâsları, Kurân İlimleri ve Hadîs, Dinler ve Uygulamalı İrfân bölümleri ile Din Felsefesi lisansüstü programı ve İlim Tarihi

\footnotetext{
8 Tahran Üniversitesinde yapılan bazı lisansüstü tezlerin listesi için bk. Ma'sume Ebû'l-Fazlî, “el-Buhûsu'lKur'âniyye fî câmiât-i Tahran (Utrûhâtu merhaletu'd-doktorâ fî kısmi'l-lügati'L-arabiyye ve âdâbihâ: nemûzecen)", el-Utrûhâtu'l-ilmiyye fi'd-dirâsâti'l-islâmiyye-dirâsetun mukârinetun beyne'l-âlemi'l-İslâmî ve'l Garb II. ed. Bilal Gökkır vd. (İstanbul: İlim Yayma Vakfi Kur'an ve Tefsir Akademisi, 2018), 2/295-300; İran'daki diğer üniversitelerde Kur'ân ve tefsîr alanına kaleme alınan bazı tezler için bk. Seyyide Fâtıma Huseynî Mîrsafî-Ma’suma Sâdât Huseynî Mîrsafî, “el-Utrûhâtu'l-ilmiyye fî̀d-dirâsâti'l-Kur'âniyye fî’l Cumhuriyyeti'l-İslâmiyyeti'l-İrâniyye”, el-Utrûhâtu'l-ilmiyye fìd-dirâsâti'l-islâmiyye- Dirâsetun mukârinetun beyne'l-âlemi'l-islâmî ve'l Garb II, ed. Bilal Gökkır vd, (İstanbul: İlim Yayma Vakfı Kur'an ve Tefsir Akademisi 2018), 2/303-304.

9 Pâyigâh-i Mecellât-i Tehassüsî Nur, “Noormags” (Erişim 18.11.2021).

10 Bu tarih fakültenin resmî sitesinde 1344/1965 belirtilmesine rağmen Nurullah Kesâyî tarafından 1343/1964 olarak kaydedilmiştir. Bk. Nurullah Kesâyî, “Doktor Tâhirî ve Gurûh-i Edyân ve İrfân Dânişkede-i İlahiyat ve Maârif-i İslâmî”, Tahkikât-i İslâmî 1 (1370/1990), 41.
} 
Araştırma merkezi ile eğitim-öğretim ve araştırma hayatına devam etmektedir. ${ }^{11}$ Fakültede 1348/1969-1349/1970 dönemi itibariyle lisans eğitiminin yanı sıra birçok bölümde yüksek lisans ve doktora düzeyinde eğitim verilmeye başlanmıştır. Fakültenin kuruluş felsefesinde Şiî mezhebinin diğer İslâm mezhepleri ile ilişkisini tesis etmek olduğu ileri sürülmektedir. Bu minvâl üzere 1329/1950 yılında Şafiî ve Hanefî fikhı bölümü açılmışsa da çok geçmeden Hanefî Fıkhı bölümü kapatılmıştır. ${ }^{12}$

Farklı bölümlerle İslâmî ilimlerde ihtisâslaşmayı amaçlayan bu fakülte aynı zamanda yayın faaliyetlerine de devam etmektedir. Bu minvalde her bölümün kendisine ait dergisi bulunmakta ve bölümle ilgili araştırmalar burada yayımlanmaktadır. Araştırmamızın merkezinde olan tefsîr bölümü ile ilgili de bir dergi bulunmaktadır. Bu dergi Kur'ân ve hadîs araştırmalarını içine alan Pejûheşhâ-yi Kur'ân ve Hadîs adı altında 1388/2008 yılında yayın hayatına başlamıştır. Derginin temel amacı günümüzde tartışllan meselelere cevaplar üretme, farklı görüşlerin eleştirisi ve yeni fikirlerin ortaya atılması şeklindedir. Derginin yayın dili Farsça olup İlkbahar-Yaz ve Sonbahar-Kış dönemleri olmak üzere yılda iki kez elektronik ortamda yayımlanmaktadır. Dergi, ISC, SID, NOORMAGS ve MAGIRAN gibi ulusal ve uluslararası veri tabanlarında taranmaktadır. Bu derginin adından da anlaşılacağı üzere Kur'ân ilimleri'nin yanı sıra hadîs ilmiyle ilgili araştırmalar da yapılmaktadır. Dergide yayımlanan makalelere bakıldığında çoğunlukla Şî̂ âlimlerin eserleri çerçevesinde kaleme alınan mütâlaâlar olduğu görülmektedir. ${ }^{13}$

\section{2. İlahiyat Fakültesinde Lisans Düzeyinde Tefsîr Eğitimi}

İlahiyat Fakültesi İlahiyat ilimlerinde uzman yetiştirme misyonu doğrultusunda bölümlere ayrılmıştır. Bu bağlamda tefsîr eğitimi, Kur'ân İlimleri ve Hadîs bölümü bünyesinde verilmektedir. İslâm'ın iki temel kaynağının birlikte ele alındığı bu bölümün gâyesi Kur'ân ve hadîsle ilgili temel kaynakları göstererek bu alan hakkında araştırma ve inceleme yöntemlerini öğretmektir. Bu bağlamda çoğunlukla -ileride zikri geçeceği üzere- Şî̂ kaynaklar esâs alınmaktadır.

Bu bölümden mezun olanlar İran'daki eğitim kurumlarında, idâri kurumlarda, dînî ve kültürel merkezlerde görev alma imkanına sahip olmaktadırlar. Ayrıca İslâm İş̧̂ad Bakanlığına bağlı olarak İslâmî Tebliğ kuruluşlarında, Kur'ân araştırma merkezlerinde; dînî, kültürel merkez ve müesseselerde, radyo ve televizyon kurumlarında çalışabilmektedirler. ${ }^{14}$

Kur'ân ilimleri ve hadîste yetkin şahsiyetler yetiştirmeyi amaçlayan bölüm, bu doğrultuda bir eğitim müfredatı hazırlamıștır. Buna göre ders müfredatı umûmî, pâye (temel), tahassusî (uzmanlık) ve seçmeli dersler şeklinde kategorize edilmiştir. Bu bölümde hadîs ilmi ile alakalı dersler bulunsa da tefsîr ile ilgili derslere daha fazla yer

\footnotetext{
Bk. Dânişgâh-i Tahran, "Dânişkede-i İlahiyat ve Maârif-i İslâmî” (Erişim 24.03.2021)

Kesâyî, “Doktor Tâhirî ve Gurûh-i Edyân ve İrfân Dânişkede-i İlahiyat ve Maârif-i İslâmî”, 40.

Dânişkede-i İlahiyat ve Maârif-i İslâmî, "Pejûheşhâ-yi Kurân ve Hadîs” (Erișim 29.11.2021)

Bk. Dânişkede-i İlahiyat ve Maârif-i İslâmî, “Ulûm-i Kur’ân ve Hadîs” (Erişim 24.03.2021)
} 
verildiği görülmektedir. Bölümün ders listesini ve kredi miktarını şu şekilde bir tabloda vermek mümkündür.

\begin{tabular}{|l|l|}
\hline Ders Türü & Ders Kredisi \\
\hline Umûmî (Üniversite tarafından Konulan Zorunlu Dersler) & 12 \\
\hline Pâye (Temel Dersler) & 32 \\
\hline Tahassusî (Uzmanlık Dersleri) & 56 \\
\hline Seçmeli Dersler & 35 \\
\hline Toplam & 135 \\
\hline
\end{tabular}

Tablo 1: Ders Kredileri Çizelgesi

Tablo 1'de de görüldüğü üzere umumî ders listesinde 12 kredi okutulmaktadır. Bunlar Farsça, İngilizce, Spor, Beden Eğitimi, Aile Bilgisi ve İslâm İnkılâbı derslerinden oluşmaktadır. Pâye olarak isimlendirilen temel dersler başlığı altında ise Kur'ân Tercümesi ve Okuma Atölyesi 1-2, Uygulamalı Sarf 1-2, Uygulamalı Nahiv 1-2, Mantık, Kelâm İlmi, İslâm Hukuk Esâsları ve Fikhın Temel Çerçevesi, İslâm Tarihi, Dinler Tarihi, Kur'ân Öğretim Becerisi, Bilimsel Araştırma Yöntemleri ve Bilgisayar-Sanal Âlem gibi daha çok genel içerikli dersler yer almaktadır. ${ }^{15}$

Bölümün ana omurgasını oluşturan dersler ise tahassusî (uzmanlık) kategorisi altında verilmektedir. Bu kısımdaki dersler hem hadîs hem de Kur'ân ilimlerini kapsayacak şekilde düzenlenmiştir. Burada hadîs alanına yönelik derslerin isimlerini vermekle yetinilecek, Kur'ân ilimleri bölümündeki dersler üzerinde durulacaktır.

Hadîs bölümü ile ilintili olarak Hadîs Tarihi, Hadîs Edebiyatı ${ }^{16}$, Hadîs Usûulü ${ }^{17}$, Fıkhu'lHadîs I-II-III ${ }^{18} \mathrm{vb}$. dersler yer almaktadır. Ayrıca hem hadîs hem de tefsîr alanına yönelik bazı uzmanlık dersleri de vardır. Bunlardan biri Uzmanlık Dili dersidir. Bu derste Kur'ân ve hadîs araştırmalarına yönelik akademik İngilizce eğitimi verilmektedir. $\mathrm{Bu}$ bağlamda her iki alana yönelik İngilizce metinler okunmakta ve metinler üzerinde tartışmalar yapılmaktadır. ${ }^{19}$ Bir diğer ders ise iki dönem halinde okutulan Uzmanlı Alanına Yönelik Metinlerin Okunması ve Tercümesi dersidir. Burada alana yönelik Arapça metinlerin tercüme yöntemleri işlenmektedir. ${ }^{20}$

15 Vezâret-i ‘Ulûm Tahkikât ve Fenâverî, Bernâme-i Dersî (Rişte-i ‘Ulûm-i Kur'ân ve Hadîs), (b.y: y.y, 1395/2016), 16-43.

16 Hadîs Tarihi ve Hadîs Edebiyâtı derslerinde temel kaynak bağlamında Mecîd Maârif'in Târih-i 'umûmî-yi hadîs'i ve Ahmed Pâkteçî̀nin Târîh-i hadîs'i adlı eserler takip edilmektedir. Bk. Vezâret-i 'Ulûm, Bernâme-i Dersî (Rişte-i 'Ulûm-i Kur'ân ve Hadîs), 81-87.

17 Burada ise Şâdî Nefîsî’nin Dirâyetu'l-hadîs adlı eseri üzerinden ders etüt edilmektedir. Bk. Vezâret-i 'Ulûm, Bernâme-i Dersî (Rişte-i 'Ulûm-i Kur'ân ve Hadîs), 88-89.

18 Abdulhâdî Mes'udî’nin Reveş-i fehm-i hadîs isimli eseri takip edilen temel kaynaklar arasında yer almakla birlikte bunun dışında birçok eser daha bulunmaktadır. Bk. Vezâret-i ‘Ulûm, Bernâme-i Dersî (Rişte-i 'Ulûm-i Kur'ân ve Hadîs), 90-95.

19 Vezâret-i ‘Ulûm, Bernâme-i Dersî (Rişte-i ‘Ulûm-i Kur'ân ve Hadîs), 45-46.

20 Vezâret-i 'Ulûm, Bernâme-i Dersî (Rişte-i ‘Ulûm-i Kur'ân ve Hadîs), 47-48. 
Kur'ân ilimleri ile ilgili ders muhtevalarına geçmeden önce tedrîs edilen kaynaklar hakkında ön bilgi vermek yerinde olacaktır. Derslerde takip edilen kaynaklar çoğunlukla Vezâret-i 'Ulûm, Tahkikât ve Fenâverî (Bilim, Araştırma ve Teknoloji Bakanlığı) 'ye bağlı olan Merkez-i Hemâhengî-yi Tevessu-i Pejûheş ve Âmuzeş-i “Âlîy-i Kur'ânî-yi Kişver ${ }^{21}$ ve Sâzmân-i Mutâlaa ve Tedvîn-i Kutub-i 'Ulûm-i İnsânî-yi Dânışgahhâ (Semt) ${ }^{22}$ kurumlarından çıkmaktadır. Ayrıca söz konusu kurumların gözetiminde yayınlanan eserler aslî kaynaklar arasında yer almaktadır. Bu kurum çatısı altında neşredilen eserler ders adı ve içeriğiyle uyumlu olarak telif edilmektedir.

\subsection{Kur'ân İlimleri Ders Müfredat1}

Daha önce ifade edildiği üzere ders müfredatı dört kısım halinde düzenlenmiştir. Bunlar arasında bulunan uzmanlık derslerinde doğrudan Şî̂ düşüncesi ile ilintili olan dersler de okutulmaktadır. Bu derslerin başında Hz. Ali'ye nispet edilen Nehcü'l-Belâga eseri ile müsemma olan Nehcü'l-Belâga'ya Girişş ${ }^{23}$ dersi gelmektedir. Burada asıl olarak Şerîf er-Râdî (ö. 406/1015) tarafından derlenen ve Hz. Ali'ye ait olduğu iddia edilen içinde hutbeler, hitâbeler, emirnâmeler, resmî ve özel mektuplar, öğütler ve vecizelerin yer aldığı eser işlenmektedir. ${ }^{24}$ Ayrıca Ziyârât-i Me'sûre, Duâlar ve Sahîfe-i Seccâdiye'ye Girişs ${ }^{25}$ derslerinde de İmâmiyye ekolü tarafından sistematize edilen ve mezhebin temel yapı taşları arasında yer alan Hz. Ali başta olmak üzere diğer imâmzâdelerden nakledilen duâların yer aldığı kaynaklar da takip edilmektedir. ${ }^{26}$

Diğer taraftan uzmanlık (tahassusî) dersleri içerisinde her ne kadar doğrudan Şia mezhebinde temel kaynak olarak kabul edilen yukarıda bahsi geçen eserler okutulsa da ağırlıklı olarak Kur'ân ve tefsîr ilmî ile ilişkili dersler üzerinde durulmaktadır. Bu dersler uzmanlık (tahassusî) ve seçmeli dersler başlığı altında verilmektedir.

21 Söz konusu kurum hakkında daha geniş bilgi için Bk. Vezâret-i 'Ulûm, "Merkez-i Hemâhengî-yi Tevessu-i Pejûheş ve Âmuzeş-i ‘Âlî-yi Kur’ânî-yi Kişver” (Erişim 06.04.2021).

22 Vezâret-i 'Ulûm, Tahkikât ve Fenâverî (Bilim, Araştırma ve Teknoloji Bakanlığı) bünyesinde faaliyetlerini yürüten bu kurum, özellikle sosyal bilimler ve İslâmî alanlarda kitap basım ve benzeri farklı görevleri yerine getirmektedir. Kurum hakkında daha detaylı bilgi için Bk. Vezâret-i “Ulûm, “Tarihçe-i Semt”" (Erişim 06.04.2021).

23 Bu derste takip edilen eserler arasında Murtazâ Mutahharî’nin Seyrî der nehci'l-belâga adlı kitabı zikredilebilir. Bk. Vezâret-i 'Ulûm, Bernâme-i Dersî (Rişte-i ‘Ulûm-i Kur'ân ve Hadîs), 96-97.

${ }^{24}$ Bk. İsmail Durmuş, "Nehcü'l-Beâga”, Türkiye Diyanet Vakfi İslâm Ansiklopedisi (İstanbul: Türkiye Diyanet Vakf1, 2006), 32/538-540.

25 Muhammed Muhammedî Rey Şehrî, Nehcü'd-dua'sı okutulmaktadır. Bk. Vezâret-i ‘Ulûm, Bernâme-i Dersî (Rişte-i 'Ulûm-i Kur'ân ve Hadîs), 98-99.

26 Temel dersler başlığı altında Belâgat 1-2 dersleri de verilmektedir. Bu ders bağlamında Şiî kaynakların yanı sıra Modern dönem Ehl-i Sünnet âlimleri tarafından telif edilmiş eserler de takip edilmektedir. Mısırlı âlim Ahmed Hâş̧imînnin Cevâhuru'l-belâga'sı bunlar arasındadır. Sünnî kaynaklara yer verilmekle birlikte Şî̂ kaynaklar daha çoktur. Örnek eserler için bkz. Bk. Vezâret-i 'Ulûm, Bernâme-i Dersî (Rişte-i 'Ulûm-i Kur'ân ve Hadîs), 76-80. 


\subsubsection{Uzmanlik (Tahassusî) Dersleri}

\section{- Kur'ân Müfredatı}

$\mathrm{Bu}$ derste Kur'ân kavramlarına ait kaynaklara nasıl inileceğine dair yöntem öğretilmektedir. Bu bağlamda iştikâk ve türevleri, garibu'l-Kur'ân, lafzî-manevî iştirâk, furûku'l-lugaviyye, ezdâd, vücûh ve tazmîn konularının yanı sıra Kur'ân'da geçen kelimelerin nüzûl dönemindeki Arap kültürü ile irtibatı ve siyâk gibi konular da irdelenmektedir. Ayrıca Kur'ân'daki kavramlara yönelik yazılan kaynaklar da tanıtılmaktadır. ${ }^{27}$ Derste tâkip edilen temel eser ise Merkez-i Hemâhengîy-i Tevessu-i Pejûheş ve Âmuzeş-i 'Âlîy-i Kur'ânîy-i Kişver tarafindan hazırlanan Müfredât-i Kur'ân'dır. ${ }^{28}$

\section{- 'Ulûmu'l-Kur'ân I-IV}

Dört dönemden oluşan bu dersin birinci döneminde Kur'ân hakkındaki temel bilgiler kapsamında; sûre, cüz, vahiy ve çeşitleri, nüzûl bağlamında ilk ve son inen sûre(ler) ve âyet(ler) ${ }^{29}$; ikinci döneminde Kur'ân'ın i'câzı ve tahrîfi birçok boyutu ile birlikte ele alınmaktadır. ${ }^{30}$ Üçüncü dönemde ise mekkî-medenî, nâsih-mensûh, esbâbu'n-nüzûl ve muhkem-müteşâbih konuları işlenmektedir. Bu dersin son aşaması olan dördüncü dönemde ise daha çok fıkıh usûlü ile ilişkili olan âmm- hâs, mutlakmukayyed, mücmel-mübeyyen, mefhûm-mantûk ve kısımları gibi hususlar üzerinde tafsilatlı bir şekilde durulmaktadır. 'Ulûmu'l-Kur'ân dersinin ilk üç aşamasında Muhammed Ma'rifet' in 'Ulûmu'l-Kur' ân ${ }^{31}$ isimli eseri esâs alınırken; 'Ulûmu'l-Kur'ân IV dersinde ise Merkez-i Hemâhengî̀nin Delâlethâ-yi Kur'ân-i Kerîm isimli eseri takip edilmektedir. ${ }^{32}$

\section{- Kur'ân'ın Yazımı ve Kırâatler Tarihi (Kur'ân Tarihi)}

Bu derste peygamberin tebliğ ve öğretim metodu, Kur'ân'in nebevî döneminde cem' ve tedvîni, dört halîfe döneminde cem', resmü'l-mushaf, Kur'ân'ın noktalanması, Kur'ân'ın sûre ve âyetlere göre taksimi, kırâatlerde ihtilâfın zuhûru, yedi kurrâ, yedi kırâat, Kur'ân'ın yedi harf üzere nâzil olması, Kur'ân'ın yazım adâbı ve mushaf haline getirilmesi ve dünyadaki meşhur mushaflar gibi konular ele alınmaktadır. Âyetullah Hûî-Seyyid Ebû'l-Kasım'in el-Beyân fî Tefsîri'l-Kur'ân ve Muhammed Hâdî Ma'rifet'in Târîh-i Kur'ân isimli eserler ders kaynakları olarak kullanılmaktadır. ${ }^{33}$

Vezâret-i 'Ulûm, Bernâme-i Dersî (Rişte-i 'Ulûm-i Kur'ân ve Hadîs), 51.

Bk. Vezâret-i 'Ulûm, Bernâme-i Dersî (Rişte-i 'Ulûm-i Kur'ân ve Hadîs), 51.

Ulûmu'l-Kur'ân I olarak adlandırılan bu derste üzerinde etüt edilen temel materyaller arasında Muhammed Bâkır Hüccetî̀nin Pejûheşî der târih-i Kur'ân-i Kerîm'i, Muhammed Hâdî Ma'rifet'in Ulumu'l-Kur'ân'1, Ebû'l-Fazl Mîr Muhammedî Zernedî’nin Târih ve ulûm-i Kur'ân'1 yer almaktadır. Bk. Vezâret-i ‘Ulûm, Bernâme-i Dersî (Rişte-i 'Ulûm-i Kur'ân ve Hadîs), 53-54.

30 Aslî kaynaklar arasında Muhammed Hüseyin Tabâtabâ̂̀'nin I'câz-i Kur'ân'1, Muhammed Ma'rifet'in ‘Ulûm-i Kur'ân'1, Rızâ Müeddeb'in I'câz-i Kur'ân der nazar-i Ehl-i Beyt ve Abdullah Cevâd Âmilî̀nin Nezâhet-i Kur'ân ez tahrîf adlı eserleri yer almaktadır. Bk. Vezâret-i 'Ulûm, Bernâme-i Dersî (Rişte-i ‘Ulûm-i Kur'ân ve Hadîs), 55.

31 Bk. Vezâret-i 'Ulûm, Bernâme-i Dersî (Rişte-i 'Ulûm-i Kur'ân ve Hadîs), 57.

32 Bk. Vezâret-i ‘Ulûm, Tahkikât ve Fenâverî, Bernâme-i Dersî (Rişte-i 'Ulûm-i Kur'ân ve Hadîs), 59-60.

33 Bk. Vezâret-i 'Ulûm, Bernâme-i Dersî (Rişte-i 'Ulûm-i Kur'ân ve Hadîs), 61-62. 


\section{- Kur'ân Tefsîri Kaynaklarını Tanıma}

Bu derste ekol kavramının kavramsal çerçevesi, tefsîr çeşitleri, Şiî tefsîrlerden Muhammed Hüseyin b. Ali el-Askerî (ö. 260/874), Furât el-Kûfî (ö. 310/922), Ayyâşî (ö. 320/932), Kummî (ö.329/941), Tûsî (ö. 460/1067), Tabersî (ö. 548/1154), Sâfî (ö. 1090/1679), Tabâtabâî (ö. 1981), Mekârim Şirâzînnin tefsîri, konulu tefsîr babından olarak Seyyid Muhammed Bakır Sadr'ın Medresetü'l-Kur'âniyye, Cafer Sübhani'nin Menşûr-i câvîd, Nâsır Mekârim'in Peyâm-i Kur'ân ve Muhammed Takî Misbâh Yezdînnin Maârif-i Kur'ân'ı genel hatlarıyla tanıtılmaktadır. Ehl-i Sünnet tefsîr külliyatından da Râzînnin (ö. 606/1210) Mefâtih'i, Âlûsînin (ö. 1270/1854) Ruhû'l-meânî̉si ve Seyyid Kutub'un (ö. 1966) fi Zilâli'l-Kurân gibi temel tefsîr eserleri incelenmeye tabi tutulurken konulu tefsîr olarak ise Semî' 'Âtıf Zeyn'in et-Tefsîru'l-mevzuî li'l-Kur'âni'l-Kerîm ve Mustafa Müslim'in editörlügünde hazırlanan et-Tefsîru'l-mevzûû li's-süveri'l-Kur'âni'lKerîm adlı eser üzerinde durulmaktadır. Bu derste takip edilen kaynaklar arasında Rizâ Üstâdînnin Âşinâyîbâ Tefâsîr-i Kur'ân-i Mecîd ve Müfessirân, Receb Alî Mazlûmînnin Tefsîri Şia ve Tefsîr Nivisân-i ân Mekteb, Muhammed Hâdî Ma'rifet'in et-Tefsîr ve'l-Müfessirûn fi Sevbihi'l-Kaşîb, Ali Ekber Bâbâînnin Mekâtib-i tefsîrî ve Muhammed Hüseyin Zehebînnin et-Tefsîr ve'l-Müfessirûn isimli eserleri zikredilebilir. ${ }^{34}$

\section{- Kur'ân-1 Kerîm Tefsîrinin Kaideleri}

Merkez-i Hemâhengî'nin Usûl ve Mukâddimât-i Tefsîr ${ }^{35}$ adıyla yayımladığı eser esâs alınarak tedris edilen bu ders, üç bölüm halinde işlenmektedir. Dersin girizgâhında tefsîr, te'vîl, rivâyet-dirâyet tefsîri, temel, asl ve kâide kavramları ele alınmakta; akabinde Kur'ân tefsîrinin temellerinin açılanması adlı üst başlıkta Kur'ân metninin vahiy oluşu, tertîbi, Kur'ân sûre ve âyetlerinin yapısı, kelâmullah, Kur'ân ve kırâat ayrımı, Kur'ân'ın muhatapları, herkes için anlaşılır olması ve siyâk gibi benzeri konular irdelenmektedir. Kur'ân tefsîrinin kâidelerinin açılanması başlığı altında ise sahih tefsîri seçmek için siyâkta bulunan karîne ve şevâhidleri göz önünde bulundurma, sahih rivâyet tefsîrini dirâyet(memdûh)'e tercih etme, Kur'ân âyetlerini bazı yönleri ile takyidden kaçınma, âyetlerin tefsîrini meşhur tefsîrlerdeki yorumlarla sınırlandırmama, Kur'ân'ın işârî ve bâtınî tefsîrlerinde zâhir-bâtın çizgisini koruma, isrâiliyyât vb. hususların Kur'ân tefsîrine konulmasından kaçınma gibi daha birçok konu zikri geçen başlık altında işlenmektedir. ${ }^{36}$

\section{- Kur'ân Tefsîri I-II-III}

Üç dönemde okutulan bu dersin ilk döneminde Tahrîm'den Mücâdele'ye, ikinci döneminde Hadîd'ten Kamer'e kadarki sûreler genel hatlarıyla işlenirken üçüncü dönemde ise Necm sûresinden Kâf sûresine kadarki sûreler garip lafizlar, belâgî ve edebî nükteler ve çıkarılması gereken dersler yönünden incelenmektedir. Burada Merkez-i Hemâhengî’nin Mushaf-i Âmuzeşî Hızb-i Mufassal adlı kaynak takip edilmektedir ${ }^{37}$

\footnotetext{
Vezâret-i ‘Ulûm, Bernâme-i Dersî (Rişte-i 'Ulûm-i Kur'ân ve Hadîs), 63-65.

Vezâret-i 'Ulûm, Bernâme-i Dersî (Rişte-i 'Ulûm-i Kur'ân ve Hadîs), 66.

Vezâret-i 'Ulûm, Bernâme-i Dersî (Rişte-i 'Ulûm-i Kur'ân ve Hadîs), 66-67.

Vezâret-i ‘Ulûm, Bernâme-i Dersî (Rişte-i 'Ulûm-i Kur'ân ve Hadîs), 68-70.
} 


\section{- Konulu/Temâtik/Mevzû̂î Tefsîr I-II}

Hüseyin Murâdî Zencânî ve Muhammed Ali Lisânî tarafından kaleme alınan Reveşi Tahkîk-i Mevzûî̀ der Kur'ân-i Kerîm adlı kitabın kaynak olarak alındığı bu ders iki dönemden oluşmaktadır. Konulu Tefsîr I'de konunun teorik boyutu ele alınırken ikinci dönemde ise daha çok âyetler üzerinden okumalar yapılmaktadır. Söz gelimi ilgili dersin ikinci döneminde sekiz konu üzerinde durulmuş, ilgili her bir konu ise iki oturum şeklinde düzenlenmiştir. Bu derste ele alınan konular arasında "Kur'ân'da Şerh-u Sadr", "Kur'ân'da İbtilâ", "Kur'ân'da Tefekkür”, "Kur'ân'da Tuğyan ve Tâğût" ve "Kur'ân'da Hz. Âdem kıssası" ve benzeri konular zikredilebilir. ${ }^{38}$

\section{- Belâgat İlmi ve Kur'ân'1 Kerîm'in Estetiği I-II}

İki dönem halinde okutulan bu dersin ilk döneminde Arap dilinin nüzûl öncesi ve sonrasındaki durumu, belâgat kavramının ilgili kaynaklar ışı̆̆ında kavramsal çerçevesi işlenmekte; ardından belâgat meânî, beyân ve bedî̀ şeklinde klasik taksim üzerinden üç ana başlığa ayrıldıktan sonra kelâm, haber, inşâ, müsned, müsned ileyh, itlâk, takyîd, kasr, fasl, vasl, icâz, müsâvât, itnâb, teşbih, istiâre ve kinâye gibi belâgatın temel konuları ele alınmaktadır. Dersin ikinci döneminde ise daha çok Kur'ân özelinde tekrarlar, müşâkele, iştikâk, fasılalar ve leffü neşr gibi belâgat konuları üzerinde durulmaktadır. Burada kâhir ekseriyetle modern dönemde telif edilen belâgat eserleri takip edilmektedir. Ahmed Hâşimînnin Cevâhirü'l-Belâğa'sl, Seyyid İbrâhim Dîbâcînnin Bidâyetü'l-Belâğa'sı, Yedullâh Nusayriyyân'ın 'Ulûm-i Belâgat ve I'câz-i Kur'ân'ı ve Emîr elEmînî'nin Tehzîbu Cevâhiri'l-Belâğa'sı üzerinde etüt edilen eserlerdir. ${ }^{39}$

\subsubsection{Seçmeli Dersler}

\section{- Batı'da Kur'ân Araştırmalarının Seyri ve Oryantalizm Tarihi}

Târih-i İstişrâk ve Seyr-i Tatavvur-i Mutâla'ât-i Kur'ânî der Ğarb adlı kaynağın baz alındığı bu derste istişrâk kavramının genel çerçevesi üzerinde durulduktan sonra siyâsî, dînî, iktisâdî ve ilmî açıdan oryantalizmin tarihsel arka planı incelenmektedir. Oryantalistlerin araştırmalarında kullandıkları yöntemler, kadın ve cihâd gibi konularda oryantalistlerin fikirleri konu edilmektedir. ${ }^{40}$

\section{- Kur'ân-1 Kerîm'in Yapısal Tefsîri}

'Ulûmu'l-Kur'ân özelinde sûrelerin başı ve sonu arasındaki münâsebeti ve özellikleri, sûrelerin tanıtımı, Hz. Peygamber'in ve Ehl-i Beyt'in sîretinde sûrenin yeri ve önemi, İslâm fikhında sûre ile ilintili hükümler, sûrelerin tümünün taksîmâtı, birbirleri ile olan benzerliği, içeriği ve yapısı üzerinde durulmakta son olarak seçilen bazı sûreler üzerinde detaylı bir şekilde durulmaktadır. Burada da yine aslî kaynak olarak Merkez-i Hemâhengî tarafından basılan Tefsîr-i Sâhtârîy-i Kur'ân-i Kerîm isimli

\footnotetext{
Vezâret-i ‘Ulûm, Bernâme-i Dersî (Rişte-i ‘Ulûm-i Kur'ân ve Hadîs), 75.

Vezâret-i “Ulûm, Bernâme-i Dersî (Rişte-i 'Ulûm-i Kur'ân ve Hadîs), 76-80.

Vezâret-i ‘Ulûm, Bernâme-i Dersî (Rişte-i ‘Ulûm-i Kur'ân ve Hadîs), 101-102.
} 
eser okutulmaktadır. Bu dersteki tâlî kaynaklar içerisinde Şiî eserler büyük bir yer tutsa da Sünnî literatüre de yer verilmiştir. ${ }^{41}$

\section{- Semantik I-II}

Arapçada "İlmu'd-Delâle" Farsça'da ise "Manâş̧inâsî" olarak isimlendirilen bu ders iki dönemden oluşmaktadır. Delâlet ilmi I'de kelime ve cümle düzeyinde anlam ilişkileri olmak üzere iki başlık altında delâlet, dâl, medlûl, eşanlamlılar, farklı manaya sahip kelimeler, zit anlamlılar ve benzeri konular ele alınırken dersin devamı olan ikinci dönemde ise mana ve mananın değişimi başlığı altında istiâre, i'câz, anlam genişlemesi, anlam daralması; lafzın değişimi başlığı altında mananın değişip değişmemesi gibi konular ele alınmaktadır. Bu dersin son aşamasında ise konu bağlamında tatbîkî örnekler üzerinde durulmaktadır. Bu dersin her iki döneminde de aslî kaynak olarak Merkez-i Hemâhengî’nin Manâşinâsî adlı kitap esâs alınmaktadır. ${ }^{42}$

\section{- Kutsal Kitap (Tevrat-İncil) ve Kur'ân'da Peygamber Kıssaları}

Kur'ân ve 'Ahdeyn'de Peygamber Kıssaları adlı derste İslâm'ın Yahudi ve Hristiyanlıkla mukayesesi ortaya konulduktan sonra kıssa kavramının etimolojik kökeni, Kitab-1 Mukaddeste kıssanın önemi, kıssayı oluşturan temel unsurlar, kıssatarih-mitoloji arasındaki ayrımlar ve isrâiliyyât meselesi ele alınmaktadır. Ardından Kur'ân ve Tevrât-Zebûr'da ortak olarak üzerinde durulan Âdem, İbrâhim, Mûsâ, Zekeriyyâ, Yahyâ ve Meryem-İsâ gibi peygamberlerle ilgili kıssalar karşılaştırmalı olarak tahlil edilmekte, son olarak da İslâm peygamberi ve Ahdeyn konusu incelenmektedir. Bu derste Eşrefî Abbâs'ın Mukayese-i Kasas der Kur'ân ve 'Ahdeyn isimli eseri aslî kaynak olarak takip edilmektedir. ${ }^{43}$

\section{- Kur'ân Araştırmalarında Modern Akımlar}

Merkez-i Hemâhengî tarafından hazırlanan Cereyânşinâsîy-i Mutâlaât-i Kur'ânîy-i Muâsır adlı kaynağın esâs alındığı bu derste modern akımlar, Batı'da Kur'ân Çalışmaları ve İslâm Dünyasında Yeni Kur'ân Çalışmaları olmak üzere iki üst başlığa ayrılmaktadır. Birinci kısımda Kur'ân metni ile ilgili çalışmalar isimli alt başlıkta Nöldeke (ö. 1930) ${ }^{44}$, Richard Bell (ö. 1952) ${ }^{45}$ ve Blachere (ö. 1973) ${ }^{46}$ gibi oryantalistlerin görüşleri ekseninde Kur'ân tarihi konuları işlenmektedir. Kur'ân muhtevası ile ilgili çalışmalar isimli diğer bir başlık altında ise yine oryantalistlerin görüşleri doğrultusundaki inanç, kıssalar, ictimâî ve kültürel meseleler ve ilmî tefsîr gibi mevzular incelenmektedir. İslâm Dünyasındaki Kur'ân Çalışmaları isimli ikinci kısımda Seyyid Kutub (ö. 1966), Tabâtabâî (ö. 1981), Muhammed Hamîdullâh (ö. 2002), Muhammed Sâdıkî Tahrânî (ö. 2011), Âzertâş Âzernuş (ö. 2021), Muhammed b. Hayre, Şehrâm Hidâyet, Mecîd Sâlihî, Hüseyin

\footnotetext{
${ }^{41}$ Vezâret-i 'Ulûm, Bernâme-i Dersî (Rişte-i 'Ulûm-i Kur'ân ve Hadîs), 103-104.

42 Vezâret-i 'Ulûm, Bernâme-i Dersî (Rişte-i 'Ulûm-i Kur'ân ve Hadîs), 105-107.

43 Vezâret-i 'Ulûm, Bernâme-i Dersî (Rişte-i 'Ulûm-i Kur'ân ve Hadîs), 108-109.

${ }_{44}$ Hakkında detaylı bilgi için bk. Hilal Görgün, "Nöldeke, Theodor", Türkiye Diyanet Vakfi İslâm Ansiklopedisi, (İstanbul: Türkiye Diyanet Vakfi, 2007), 33/217-218.

$45 \quad$ Bk. M. Manazır Ahsan, "Bell, Richard", Türkiye Diyanet Vakfi İslâm Ansiklopedisi (İstanbul: Türkiye Diyanet Vakf1, 1992), 5/423-424.

46 Bk. Hidayet Yavuz Nuhoğlu, "Blachere, Regis", Türkiye Diyanet Vakfi İslâm Ansiklopedisi (İstanbul: Türkiye Diyanet Vakf1, 1992), 4/244-245.
} 
Abdurraûf ve Ahmed Pâkteçî, gibi zevatın görüşlerinin yanı sıra selefîlerin, modernistlerin ve gelenekçilerin görüşleri; Mahmûd Ebu Reyye (ö. 1970), Gûlâm Pervîz (ö. 1985), Muhammed Tâlibî (ö. 2017), Muhammed Şahrûr (ö. 2019) ve Ahmet Subhî Mansûr gibi Misır, Tunus ve Hint alt kitasındaki Kur'âniyyûn temsilcileri incelenmektedir.

Tarihselcilik bağlamında ${ }^{47}$ ise Nasr Hâmid Ebû Zeyd (ö. 2010), Muhammed Arkoun (ö. 2010), Muhammed 'Âbid el-Câbirî (ö. 2010), Muhammed 'Ammâre (ö. 2020) ve Hasan Hanefî (ö. 2021) gibi bilginlerin görüşleri üzerinde durulmaktadır. Burada konu edilen şahısların çoğu meşhur şahıslar olsa da Tunus'lu tarihçi Hişâm Cü'eyd (ö. 2021) gibi Türk akademyasında üzerinde araştırma yapılmamış şahıslara da yer verildiği görülmektedir. ${ }^{48}$ Ders izlencesinden hareketle dikkatimizi çeken hususlardan bir tanesi Kur'âniyyûn temsilcileri arasında Mısır ve Hint alt kıtasındaki mensuplar zikredilirken İran'dakiler üzerinde durulmamasıdır. Zira İran'da Şerîat Senglecî (ö. $1943)^{49}$ ve Yusuf Şu'âr (ö. 1972) gibi İranlı Kur'âniyyûn ekolüne mensup meşhur zatların olduğu bilinmektedir..$^{50}$

\section{- Tefsîr Yöntemleri}

Burada öncelikle tefsîr, te'vîl, tefsîr ekolleri ve tefsîr akımları gibi genel kavramların üzerinde durulmakta; ardından ele alınan konular tefsîr yöntemleri ve tefsîr tarzları başlıkları olmak üzere iki ana kısma ayrılmaktadır. Tefsîr yöntemleri de kendi içinde Kur'ân'ın Kur'ân ile tefsîri bağlamında Kur'ân'da Kur'ân'ın ile Kur'ân ile tefsîri, Ehl-i Beyt kaynaklarında Kur'ân'ın Kur'ân ile tefsîri ve tabiûn-sahabede Kur'ân'ın Kur'ân ile tefsiri gibi konular işlenmektedir. Rivâyet-dirayet(aklî) tefsîr metotları da Kur'ân'ın Kur'ân ile tefsîri metodundaki gibi ele alınmaktadır. Tefsîr çeşitleri isimli başlık altında tefsîrler edebî, kelâmî, ilmî, ictimâî ve irfânî şeklinde taksim edilmekte, İrfânî tefsîr başlığında metin eksenli Reşidüddîn Meybüdî'nin ${ }^{51}$ (ö. 520/1126'dan sonra) tefsîri ve Humeynî’nin ${ }^{52}$ (ö. 1989) tefsîrinden bir bölüm okutulmaktadır. Ders kapsamında aslî kaynak olarak Hemâhnegî merkezinin hazırladı̆̆ı Reveşhây-i tefsîrî adlı eser takip edilmektedir. Derste takip edilen tâlî kaynaklar arasında ise Muhammed Hâdî Ma'rifet'in et-Tefsîr ve'l-Müfessirûn fî Sevbihi'l-

47 Muhsin Demirci, Tefsir Tarihi (İstanbul: Marmara Üniversitesi İlahiyat Fakültesi Vakfı Yayınları, 2016), 251266.

48 Vezâret-i ‘Ulûm, Bernâme-i Dersî (Rişte-i 'Ulûm-i Kur'ân ve Hadîs), 110-111.

49 Bk. Habip Demir, "Çağdaş Şî̂ Islah Düşüncesinde Selefî Etkiler: Şerîat Sengleci Örneği”, Hitit Üniversitesi İlahiyat Fakültesi Dergisi 19/1 (2020), 267-269.

50 Daha geniş bilgi için bk. Zehrâ İhvân Mukaddem-Seyyid Mecîd Nebevî, "Şahsîyetşinâsî ve menba'şinâsi-yi Kur'âniyyûn”, Fâsılnâme-i Tahassusîy-i Mutâlaât-i Kur'ân ve Hadîs-i Sefine 15/57 (Kış 2018), 139-140.

51 Müellif ve eser hakkında daha geniş bilgi için bk. Rıza Kurtuluş, "Keşfü'l-esrâr", Türkiye Diyanet Vakfi İslâm Ansiklopedisi (İstanbul: Türkiye Diyanet Vakf1, 2002), 25/319. Meybudî tarafından kaleme alınan Keşfu'l-esrâr adlı on ciltlik Farsça tefsîri özellikle işâ̂î yönüyle temâyüz etmektedir. Eser bilhassa hicri altıncı asrın Farsçası ile ele alındığından önemlidir. Bu eser hakkında daha geniş bilgi için bk. Abdulvahap Yıldız, “Meybudî’nin Keşfu'l-esrâr ve 'Uddetu'l-ebrâr Adlı Tefsîri”, Tasavvuf: İlmî ve Akademik Araştırma Dergisi 7/17 (2006), 73-102. Aynı yazar tarafından kaleme alınan doktora tezi için bk. Abdullah Yıldız, Meybudî ve Keşfu'lEsrar adlı Tefsîrde Tasavvufî Kültür, (Şanlıurfa: Harran Üniv., Sosyal Bilimler Enstitüsü, Doktora Tezi, 2000).

52 Daha geniş bilgi için bk. Seyyid Mahmud Yusuf Sânî-Hüseyin Ruhânî Nejâd, "Tefsîr-i İrfânî ez-Didegâh-i İmâm Humeynî”, Kabasât 24/92 (Yaz 1398/2019), 187-211. 
Kaşîb gibi Şî̂ kaynaklar yanında Sünnî kaynaklardan olan Muhammed Hüseyin Zehebî̀nin et-Tefsîr ve'l-Müfessirûn da bulunmaktadır. ${ }^{53}$

\section{- İran ve Dünya'da Kur'ân ve Hadîs Araştırma Merkezleri}

Başta İran olmak üzere diğer ülkelerdeki Kur'ân ve hadîs merkezlerinin içeriği hakkında bilgi veren bu derste öncelikle ilgili araştırma merkezlerindeki hâkim tutum Şiî, Sünnî, Lâik, Zâhirî gibi çeşitli yönlerden taksîmâta tabi tutulmaktadır. İşlevine göre araştırma merkezleri başlığı altında Kur'ân ve hadîs sahasındaki temel araştırmalar, tefsîr, fikıh, rivâyet ve İslâm tıbbındaki araştırmalar, hadîs ve Kur'ân tarihi ile ilgili araştırmalar, katalog yazıları, elyazmaları, bunların onarımı gibi araştırma hizmetleri ele alınmaktadır. Coğrafî dağılıma göre araştırma merkezleri başlığı altında ise İran'dan Tahran, Meşhed ve İsfahan; Arap ülkelerinden Suud-i Arabistan, Mısır, Irak, Ürdün, Fas, Tunus; Asya ülkelerinden Malezya Türkiye, Rusya; Batı ülkelerinden de Almanya, Fransa, İngiltere ve Amerika olmak üzere birçok ülkedeki Kur'ân araştırma merkezlerinin muhtevası ve çalışmaları üzerinde durulmaktadır. Merkez-i Hemâhengî tarafından neşredilen ders ismi ile müsemma olan Merâkiz-i Pejûheş-i Kur'ân ve Hadîs İrân ve Cihân adlı eser bu derste takip edilen ana kaynaktır. ${ }^{54}$

Dersin muhtevası hakkında daha detaylı bilgi vermek adına söz konusu derste ele alınan bazı Kur'ân araştırma merkezlerini ve bulundukları ülkeleri şu şekilde zikredebiliriz; İran: Pejûheşgâh-i 'Ulûm-i Vahyânî-yi Maâric, Pejûheşkede-i Ferheng ve Maârif-i Kur'ân, Dânişgâh-i 'Ulûm ve Maârif-i Kur'ân-i Kerîm, Pejûheşgâh-i Beynelmilelî̀-yi el-Mustafa; Misır: El-Ezher Üniversitesi ('Ulûmu'l-Kur'ân Fakültesi); Suud-i Arabistan: Merkez-i Mutâlaât-i Tefsîri-yi Kur'ân; Sudan: Dânişgâh-i Kur'ân-i Kerîm ve 'Ulûm-i İslâmî; Tunus: Dânişgâh-i Zeytûne; Fas: Müessese-i Dâru'l-Hadîs elHüseyniyye; Endonezya: Merkez-i Mutâlaât-i Hadîsî; Malezya: Bonyâd-i Kitâbet ve Neşr-i Kur'ân; Hollanda: Mutâlaât-1 Kur'ânî; Almanya: Mutâlaât-i Kur'ânî-yi Nûr; İngiltere: Müessese-i Mutâlaât-i İsmâ̂̂liyî; Amerika: Encümen-i Beynelmilelî-yi Mutâlaât-i Kur'ânî ve Hindistan: Dâru'l-'Ulûm Diyobend. ${ }^{55}$

\section{Sonuç ve Değerlendirme}

Tahran Üniversitesi İlahiyat Fakültesi Kur'ân İlimleri bölümünde tefsîrle ilgili okutulan dersler ve kaynaklar ile ilgili bir değerlendirme yapacak olursak şunları ifade edebiliriz: Bu bölümdeki ders programı oldukça kapsayıcı olmakla birlikte gerek derslerin gerekse de kaynakların seçiminde İran'ın resmî mezhebi İsnâaşeriyye'nin dikkate alındığı müşahede edilmektedir. Zira derslerde takip edilen kaynakların çoğunun bu mezhep çerçevesinde olduğu, hatta uzmanlık derslerinde İmâmiyye firkasının baş ucu eserleri arasında yer alan Nehcü'l-Belâga, Dualar ve Sahife-i Seccâdiyye gibi kaynakların ders olarak okutulduğu görülmektedir.

Vezâret-i ‘Ulûm, Bernâme-i Dersî (Rişte-i ‘Ulûm-i Kur'ân ve Hadîs), 117-118.

Vezâret-i ‘Ulûm, Bernâme-i Dersî (Rişte-i 'Ulûm-i Kur'ân ve Hadîs), 126-127.

Mahmûd Vâizî, Merkez-i pejûheş-i Kur'ân ve Hadîs der İran ve Cihân (Kum: Müessese-i İlmî Ferhengî Dâru'l-

Hadîs, 1399/2020), 5-9. 
Derslerde mürâcaat edilen materyallerin kâhir ekseriyeti Bilim, Araştırma ve Teknoloji Bakanlığı'na bağlı Merkez-i Hemâhengî ve Sâzmân-i Mutâlaa kurumlarının süzgecinden geçmekte ve bu kurumlar tarafindan yayımlanmaktadır. Kitapların denetime tabi tutulması ilmî karmaşayı engelleme yönünden olumlu bir yöne sahip olsa da maalesef farklı fikirlerin tartışılmasına engel olması açısından olumsuz bazı yönleri haizdir. Zira akademik faaliyetlerin özgür bir şekilde icra edildiği üniversitelerde öğrencilerin fikir çeşitliliğini görme açısından birçok kaynağa başvurması var olan ilmî birikimi kavrama açısından faydalı sonuçlar doğuracaktır.

Tahran İlahiyat Fakültesindeki tefsir ilmi ve eğitimi açısından en büyük avantaj, bu ilmin bir bölüm bünyesinde ayrıntılı bir şekilde verilmesidir. Bunun yanında temel kaynakları tanıma ve alanla ilgili akademik İngilizce metin okumaları ile ilgili dersler, bu bölümdeki öğrencilerin klasik ve moderni mukayeseli olarak görmelerini sağlamaktadır. Bu sayede lisans düzeyindeki öğrenci tefsîrle ilgili geniş bir malûmata sahip olma imkânı kazanmaktadır. Diğer taraftan bu bölümün günümüz tartışmalarına kayıtsız kalmayıp özellikle 19.yy ile birlikte Kur'ân tefsîrine yeni yaklaşımlar olarak ifade edebileceğimiz tarihsellik, semantik ve oryantalistlerin Kur'ân ile ilgili fikir ve akımları lisans düzeyinde öğrencilere vermesi kayda değer bir mevzudur. Bu yönüyle tefsîr bölümünde tedrîs edilen derslerin günümüz problemlerini dikkate alan zengin bir içeriğe sahip olduğu söylenebilir.

Bu çalışma Tahran Üniversitesi İlahiyat Fakültesi'ndeki tefsîr dersleriyle ilgili müfredat hakkında genel bir giriş mahiyetindedir. Bu sebeple İlahiyat Fakültelerindeki tefsîr bölümü öğrenci profili, programın çıktıları, Kum'daki ilim havzaları başta olmak üzere ilim merkezleriyle mukâyesesi ve Şiî düşüncenin İlahiyat müfredatına etkisi gibi konular daha derinlikli çalışmalara ihtiyaç duymaktadır.

\section{Kaynakça}

Ahsan, M. Manazır. "Bell, Richard”. Türkiye Diyanet Vakfi İslâm Ansiklopedisi. 5/423-424. İstanbul: Türkiye Diyanet Vakfi, 1992.

Dânişgâh-i Tahran. "Dânişkede-i İlahiyat ve Maârif-i İslâmî". Erişim 24.03.2021. https://ftis.ut.ac.ir/

Danişgâh-i Ulûm ve Maârif-i Kurân-1 Kerîm. “Muerrefî-yi Danişgâh”. Erişim 18.11.2021. http://maarej.esra.ir/

Danişgâh-i Ulûm ve Maârif-i Kurân-1 Kerîm. "Listi Riştehâ-yi Tahsîl̂”". Erişim 18.11.2021. http://www.quran.ac.ir/

Dânişkede-i İlahiyat ve Maârif-i İslâmî. "Pejûheşhâ-yi Kur'ân ve Hadîs". Erişim 29.11.2021. https://jqst.ut.ac.ir/

Dânişkede-i İlahiyat ve Maârif-i İslâmî. “Ulûm-i Kur'ân ve Hadîs”. Erişim 24.03.2021. https://ftis.ut.ac.ir/

Demir, Habip. "Çağdaş Şiî Islah Düşüncesinde Selefî Etkiler: Şerîat Sengleci Örneği”" Hitit Üniversitesi İlahiyat Fakültesi Dergisi 19/1 (2020), 267-269. 
Demirci, Muhsin. Tefsir Tarihi. İstanbul: Marmara Üniversitesi İlahiyat Fakültesi Vakfı Yayınları, 36. Basım, 2016.

Durmuş, İsmail. "Nehcü'l-Beâga". Türkiye Diyanet Vakfi İslâm Ansiklopedisi. 32/538-540. İstanbul: Türkiye Diyanet Vakfı, 2006.

Ebû'l-Fazlî, Ma'sume. “el-Buhûsu'l-Kur'âniyye fî câmiat-i Tahran (Utrûhâtu merhaletu'd-doktorâ fî kısmi'l-lügati'L-arabiyye ve âdâbihâ: Nemûzecen)". elUtruhâtu'l-ilmiyye fi'd-dirâsâti'l-islâmiyye-dirâsetun mukârinetun beyne'l-âlemi'l-İslâmî ve'l Garb II. ed. Bilal Gökkır vd. II/295-300. İstanbul: İlim Yayma Vakfı Kur'an ve Tefsir Akademisi, 2018.

Görgün, Hilal. "Nöldeke,Theodor". Türkiye Diyanet Vakfi İslâm Ansiklopedisi. 33/217-218. İstanbul: Türkiye Diyanet Vakfi, 2007.

Kurtuluş, Rıza. "Keşfü'l-Esrâr". Türkiye Diyanet Vakfi İslâm Ansiklopedisi. 25/319. İstanbul: Türkiye Diyanet Vakfı, 2002.

Mîrsafî, Seyyide Fâtıma Huseynî vd. "el-Utruhâtu'l-i̇lmiyye fî'd-Dirâsâti'l-Kur'âniyye fî'l Cumhuriyyeti'l-İslâmiyyeti'l- İrâniyye", el-Utruhâtu'l-ilmiyye fìd-dirâsâti'lislâmiyye-Dirâsetun Mukârinetun beyne'l-âlemi'l-i̇slâmî ve'l Garb II. ed. Bilal Gökkır vd. II/303-304. İstanbul: İlim Yayma Vakfı Kur'an ve Tefsir Akademisi, 2018.

Mukaddem, Zehrâ İhvân-Nebevî, Seyyid Mecîd. "Şahsîyetşinâsî ve menba'şinâsi-yi Kur'âniyyûn". Fâsllnâme-i Tahassusîy-i Mutâlaât-i Kur'ân ve Hadîs-i Sefîne, 15/57 (K1ş 2018), 139-140.

Nuhoğlu, Hidayet Yavuz. "Blachere, Regis". Türkiye Diyanet Vakfi İslâm Ansiklopedisi. 6/244-245. İstanbul: Türkiye Diyanet Vakfi, 1992.

Pâyigâh-i Mecellât-i Tahassüsî Nur. “Noormags”. Erişim 18.11.2021. https://www.noormags.ir/view/fa/magazinesearch?SearchText=\%D9\%82\%D8\% B1\%D8\%A3\%D9\%86

Pejûheşgâh-i Ulûm ve Ferheng-i İslâmî. "Muerrefî-yi Pejûheşgâh ve Pejûheşgedehâ". Erişim

18.11.2021.

http://www.isca.ac.ir/Portal/home/?news/127800/635976/654349/-18 نغان

Pejûheşgâh-i Ulûm ve Ferheng-i İslâmî. “Guruhhâ-yi İlmî”. Erişim 18.11.2021. http://www.isca.ac.ir/Portal/home/?news/127800/649805/649811/

Pejûheşgâh-i Ulûm-i Vahyanî-yi Maâric (İsra). "Pejûheşgede-i Kur'ân ve Itret”. Erişim 18.11.2021. http://esra.ir/web/maarej/research

Pejûheşgâh-i Ulûm-i Vahyanî-yi Maâric/İsra. "Âsâr”. Erişim 18.11.2021. http://esra.ir/web/maarej/asar?

Vâizî, Mahmûd. Merkez-i Pejûheş-i Kur'ân ve Hadîs der İran ve Cihân. Kum: Müessese-i İlmî Ferhengî Dâru'l-Hadîs, 1.Basım, 1399/2020.

Vezâret-i “Ulûm Tahkikât ve Fenâverî. "Merkez-i Hemâhengî-yi Tevessu-i Pejûheş ve Âmuzeş-i “Âlîy-i Kur'ânîy-i Kişver”. Erişim 06.04.2021. https://quran.msrt.ir/fa

Vezâret-i “Ulûm Tahkikât ve Fenâverî. "Tarihçe-i Semt”, sâzmân-i Mutâlaa ve Tedvîn-i Kutub-i 'Ulûm-i İnsanî Dânışgahhâ. Erişim 06.04.2021. http://samt.ac.ir/fa

Vezâret-i 'Ulûm Tahkikât ve Fenâverî. Bernâme-i Dersî (Rişte-i 'Ulûm-i Kur'ân ve Hadîs). b.y:y.y, 1395/2016. 
Vikifikh Dânişnâme-i Havza. “Havza-i İlmiyye”. Erişim 18.11.2021.

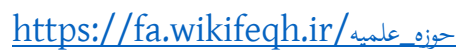

Yıldız, Abdullah. Meybudî ve Keşfu'l-Esrar adlı Tefsîrde Tasavvufî Kültür. Şanlıurfa: Harran Üniv., Sosyal Bilimler Enstitüsü, Doktora Tezi, 2000.

Yıldız, Abdulvahap. "Meybudî’nin Keşfu'l-Esrâr ve 'Uddetu'l-Ebrâr Adlı Tefsîri”. Tasavvuf: İlmî ve Akademik Araştırma Dergisi, 7/17 (2006), 73-102.

Yûsuf Sânî, Seyyid Mahmûd-Nejâd, Hüseyin Ruhânî. “Tefsîr-i İrfânî ez-Didgâh-i İmâm Humeynî”. Kabasât, 24/92 (Yaz 1398/2019), 187-211. 